\title{
Employee Satisfaction as a Mediation of Work Motivation and Training on Bank Employee Performance
}

\author{
Katharina Rosalia Dima \\ Student of Magister Management, University of Merdeka Malang, Indonesia \\ Harsono \\ Faculty of Economics and Business, University of Merdeka Malang, Indonesia \\ Harianto Respati* \\ Faculty of Economics and Business, University of Merdeka Malang
}

\begin{abstract}
This study aims to examine job satisfaction as a mediating variable of work motivation and training on employee performance. The research was conducted at a bank called "Bank Pembangunan Daerah" which is a well-known bank located in eastern Indonesia, precisely in "East Nusa Tenggara, Larantuka". The research population is all bank employees who have participated in the training program as many as 64 employees. The sampling technique is census. The research design is quantitative, that is, it examines the causal relationship by considering the mediation aspect. The analysis technique uses path analysis in the structural equation model. The results showed that employee job satisfaction was proven to mediate work motivation and training on employee performance. Job satisfaction is more able to anticipate the implementation of training than aspects of employee work motivation to improve employee performance. Unfortunately, job satisfaction is not able to become a strategy in the field of human resource management to improve employee performance. It turns out that the work training program that is regularly held by bank management has a direct impact on employee performance.
\end{abstract}

Keywords: Work Motivation, Training, Job Satisfaction, Employee Performance

DOI: $10.7176 / \mathrm{EJBM} / 14-2-01$

Publication date: January $31^{\text {st }} 2022$

\section{INTRODUCTION}

The development of banking is currently very fast so the competition in the banking world is getting tighter. " Bank Pembangunan Daerah Nusa Tenggara Timur " is required to increase competitiveness by utilizing available resources and improving service quality through work programs, namely training. The training activities are well planned and programmed. The banking business is a trusted business so the customer trust factor becomes you for a bank under study. To achieve the Bank's vision and mission, it is necessary to set several goals that are aligned with the interests of stakeholders, including the aspect of satisfaction with the best service as a customer, for the sake of a sustainable partnership relationship.

Many things have a big role in achieving performance, namely: ability, knowledge, work design, personality, motivation, leadership, organizational culture, job satisfaction, leadership style, work environment, loyalty, commitment and work discipline (Kasmir, 2016). Researchers determine motivation, training, satisfaction and employee performance to be important variables to be tested to align the competitiveness and business sustainability of a bank.

One aspect that can support the success of employees in achieving work success is motivation to do a good job (Kasmir, 2016). The motive for being able to work is expected to complete the job well. To achieve satisfactory performance, competence is needed and to achieve that can be done through several stages or ways such as formal, informal education, or training. Formal education is still not enough to achieve professional abilities, so to improve the capabilities of human resources, employees must attend training, education, and development. Motivation to do a better job is hope for improving employee performance to become professional.

One of the efforts to develop human resources is a well-planned training program. The implementation of the training produces quality human resources who are trained and have new knowledge or values so that with this all employees can easily improve their performance in carrying out their duties. The training generates new knowledge, abilities, and skills and can solve new problems, especially banking problems. The results of the research by Supatmi et al. (2013) and Saprudin (2019) prove that training has a positive impact on employee job satisfaction. The role of training is an important part of the role of human resources in the organization. This is in line with the opinion of Mangkunegara (2017) which states that one of the objectives of the training is to increase stimulation so that employees can perform optimally to achieve satisfaction. Regarding performance, the results of previous research by Supatmi et al. (2013), Indriansyah (2018), Marjaya and Pasaribu (2019) prove that training affects individual performance.

Efforts to improve employee performance, apart from the technical implementation of training, also need to 
pay attention to individual aspects that are oriented to things that can encourage employees to improve their performance. According to Kasmir (2016) that efforts to improve employee performance are one of them by paying attention to aspects of work motives, namely "work motivation". Employee work motivation is the mainstay of the organization to achieve organizational goals. This is similarly expressed by Robbins and Judge (2016) that work motivation is a willingness to make high efforts for organizational goals followed by the ability to work to meet several individual needs. The results of research by Fatmawati et al. (2014), Aziz (2016), Indriansyah (2018), Santika and Antasari (2019) prove that work motivation has a positive impact on individual performance. In contrast to the results of research by Marjaya and Pasaribu (2019) which found that motivation did not affect performance. Differences in the results of this study need to be confirmed generality between work motivation and individual performance.

The facts show that at the Larantuka Branch of "PT. Bank Pembangunan Daerah Nusa Tenggara Timur", research relating to performance and work motivation as well as training by considering aspects of employee job satisfaction has never been carried out. This research was conducted for advice to the Bank's management related to the impact of training implementation, employee motivation on their performance and measuring the level of employee job satisfaction as a consideration for future human resource planning.

\section{LITERATURE REVIEW}

Mangkunegara (2017) explains that individual performance is the result of work in quality and quantity that can be achieved by an employee in carrying out tasks following the responsibilities given to him.

Anoraga (2005) explains that work motivation is an individual's desire to work. An employee who has motivation means having a work spirit that comes from personally as the realization of the alignment of individual goals, namely expectations. Mangkunegara (2017) suggests that motivation is a condition to move employees to achieve their motives and goals. Motivation is the driving force of the individual's desire to do a job and has the power to encourage and move the individual's desire to be able to work better from time to time. The support is given to encourage employees not to be careless and to be able to realize something better (Yusuf, 2015). Miftahun and Sugiyanto (2010) state that work motivation is an effort that becomes an act to complete work and maintain or maintain actions to achieve organizational goals. Work motivation is often discussed by leaders of an organization, both openly and covertly as a strategy to achieve goals (Vithessonthi and Schwaninger, 2008). Work motivation produces positive energy that can support all the abilities that exist within a person, generating a noble desire to foster enthusiasm and partnership.

Training according to Dessler (2011) is a learning process for individuals to acquire skills according to the needs of the organization. Robbins and Judge (2008) explain the impact of training that the results of training make individuals become job satisfaction when they can complete the job well. Training or training is an organizational activity that aims to improve and develop employees in accordance with the wishes of the organization. Martoyo (2013) states that training is an activity that is intended to improve the mastery of various skills and techniques to carry out certain jobs in a relatively short time. Harras et al (2020) define training as an activity of learning, practicing, testing, finding out, developing and realizing.

Ibrahim (2007) describes employee job satisfaction in general regarding attitudes about the work they produce. Someone feels satisfied with the job if the level of needs are met, while the needs include physiological needs, security needs, social needs, esteem and prestige needs and self-fulfillment or self-fulfillment needs. Furthermore, according to Robbins and Judge (2017) said that job satisfaction is an attitude experienced by individuals towards their work in which to complete the work there are interactive activities with colleagues and superiors, following the rules and policies of work standards. Job satisfaction according to Afandi (2018) is a positive attitude from individuals including feelings and behavior towards their work through an assessment.

\section{RESEARCH HYPOTHESIS}

One of the efforts taken to be able to survive in the competition is to improve employee performance through training because employee training can improve, develop skills, and abilities that affect performance. Other important factors affect employee performance, namely motivation. Motivation is an impulse that moves employees to be able to improve their performance so that they can realize and achieve the goals set by the company. Regarding performance, the results of previous research by Supatmi et al. (2013), Indriansyah (2018), Marjaya and Pasaribu (2019) prove that training affects individual performance. Employee work motivation is the mainstay of the organization to achieve organizational goals. This is similarly expressed by Robbins and Judge (2016) that work motivation is an individual's encouragement to make high efforts for organizational goals, namely performance achievement. The results of the research by Supatmi et al. (2013) and Saprudin (2019) prove that training has a positive impact on employee job satisfaction. The role of training is an important part of the role of human resources in the organization. The results of the research by Supatmi et al. (2013) and Saprudin (2019) prove that training has a positive impact on employee job satisfaction. The role of training is an important part of the role of human resources in the organization. Robbins and Judge (2017) say that job satisfaction is an attitude 
experienced by individuals to complete a job well for the achievement of the expected performance.

H1: Work motivation and training have a significant effect on job satisfaction.

H2: Work motivation and training have a significant effect on employee performance.

H3: Job satisfaction has a significant effect on employee performance.

H4: Work motivation and training have a significant effect on employee performance through job satisfaction.

\section{RESEARCH METHOD}

The research design is a causality research design. According to Sanusi (2014) causality design is a research design designed to examine the possibility of a causal relationship between variables. Relationship and causal design are used to predict the variables studied so that researchers can state the classification of causal variables, mediating variables, and dependent variables. The approach used in this research is a quantitative approach, the process of which begins with the preparation of a theoretical model and analysis as the basis for the proposed hypothesis.

The research was conducted at a well-known bank in Eastern Indonesia, which is located in the Larantuka area. The bank is the " Bank Pembangunan Daerah Nusa Tenggara Timur Larantuka ". Based on the Bank's internal data in 2020, it was recorded that the number of bank employees who had carried out training tasks was 64 employees. The respondents of this study were employees who had attended the training. The sampling technique was census. All employees banks as research respondents. Researchers used questionnaires as a tool to collect data. Questionnaires were designed using a Likert scale with choice 5 strongly agreeing to choice 1 being strongly disagreed, the middle number being choice 3 , which is neutral.

The data analysis technique uses path analysis between variables which consists of:

Work motivation as an independent variable (X1), training as an independent variable (X2), job satisfaction as a mediating variable (Y2) and employee performance as a dependent variable (Y2). The researcher used the SPSS program to analyze the regression technique twice to get the standardized coefficients in the regression equation model.

Regression equation 1: $\mathrm{Y} 1=\mathrm{b} 1 \mathrm{X} 1+\mathrm{b} 2 \mathrm{X} 2+\mathrm{e} 1$

Regression equation 2: $\mathrm{Y} 2=\mathrm{b} 3 \mathrm{X} 1+\mathrm{b} 4 \mathrm{X} 2+\mathrm{b} 5 \mathrm{Y} 1+\mathrm{e} 2$

The structural equation model is presented in Figure 1.

\section{Figure 1. Structural equation model}

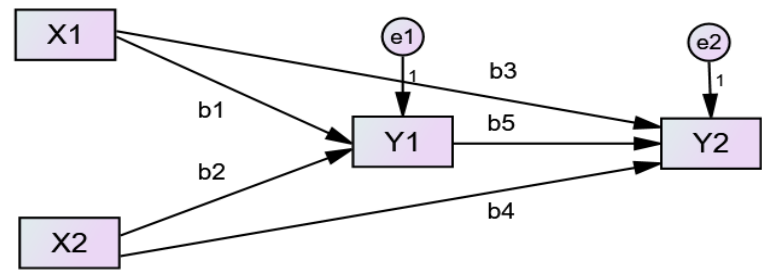

\section{RESEARCH RESULTS}

The hypothesis testing method is carried out by testing the probability value of each standardized coefficient in the regression equation model compared with an error rate of $0.05(\alpha)$. If the probability value does not exceed 0.05 , it indicates that there is an effect of the dependent variable on the dependent variable. After testing the hypothesis, then conducting a path analysis to determine the effects of direct, indirect and total effects in the structural equation model that was built. The results of hypothesis testing are presented in Table 1.

Table 1. The results of the research hypothesis test

\begin{tabular}{|c|c|c|c|c|c|}
\hline \multicolumn{3}{|c|}{ Variable } & \multirow[t]{2}{*}{ p. } & \multirow[t]{2}{*}{$\alpha$} & \multirow[t]{2}{*}{ result } \\
\hline Independent & Mediation & Dependent & & & \\
\hline $\mathrm{X} 1$ & $\mathrm{Y} 1$ & - & 0,008 & \multirow[t]{2}{*}{0,05} & \multirow{2}{*}{ H1 accepted } \\
\hline $\mathrm{X} 2$ & Y1 & - & 0,000 & & \\
\hline $\mathrm{X} 1$ & & Y2 & 0,004 & \multirow[t]{2}{*}{0,05} & \multirow{2}{*}{ H2 accepted } \\
\hline $\mathrm{X} 2$ & & Y2 & 0,000 & & \\
\hline & Y1 & Y2 & 0,012 & 0,05 & H3 accepted \\
\hline $\mathrm{X} 1$ & Y1 & Y2 & 0,008 and 0,012 & 0,05 & \multirow{2}{*}{ H4 accepted } \\
\hline $\mathrm{X} 2$ & Y1 & Y2 & 0,000 and 0,012 & 0,05 & \\
\hline
\end{tabular}

Notes:

$\mathrm{X} 1$ is work motivation

$\mathrm{X} 2$ is training

$\mathrm{Y} 1$ is job satisfaction

Y2 is employee performance 
Table 1 describes the proof of the first to fourth research hypotheses. The first research hypothesis states that work motivation and training have an effect on job satisfaction. Table 1 shows that the variable of work motivation on job satisfaction has an influence probability value of 0.008 and the training variable on job satisfaction has an influence probability value of 0.000 . Both of these probability values are less than 0.05 , meaning that the first hypothesis is accepted.

Furthermore, the second research hypothesis states that work motivation and training affect employee performance. Table 1 shows that the work motivation variable on employee performance has an influence probability value of 0.004 and the training variable on employee performance has an influence probability value of 0.000 . Both of these probability values are less than 0.05 , meaning that the second hypothesis is accepted.

The third research hypothesis states that job satisfaction has an effect on employee performance. Table 1 shows that job satisfaction on employee performance has an influence probability value of 0.012 , this probability value is less than 0.05 , meaning that the third hypothesis is accepted.

The fourth research hypothesis states that work motivation and training have an effect on employee performance mediated by job satisfaction. Table 1 shows that there is a significant effect of work motivation and training on job satisfaction and job satisfaction has a significant effect on employee performance. The existence of this influence indicates that the fourth hypothesis is accepted.

The results of testing the four research hypotheses are stated to be provable. For further path analysis, as presented in Table 2.

Table 2. Results of path analysis between research variables

\begin{tabular}{|l|c|c|c|c|}
\hline \multicolumn{1}{|c|}{ Variable } & Direct effect & p. & Indirect effect & Total effect \\
\hline X1 to Y1 & 0,295 & $0,008^{*}$ & - & - \\
\hline X1 to Y1 & 0,518 & $0,000^{*}$ & - & - \\
\hline X1 to Y2 & 0,269 & $0,004^{*}$ & - & - \\
\hline X1 to Y2 & 0,445 & $0,000^{*}$ & - & - \\
\hline Y1 to Y2 & 0,259 & $0,012^{*}$ & - & - \\
\hline X1 to Y2 with the mediation of Y1 & 0,269 & - & $0,295^{*} \mathrm{X} 0,259^{*}=0,076^{*}$ & $0,345^{*}$ \\
\hline X2 to Y2 with the mediation of Y1 & 0,445 & - & $0,518^{*} \mathrm{X} 0,259^{*}=0,134^{*}$ & $0,579^{*}$ \\
\hline
\end{tabular}

Notes:

*) indicates the level of $\mathrm{p}$. generated does not exceed $\alpha(0.05)$

$\mathrm{X} 1$ is work motivation

$\mathrm{X} 2$ is training

$\mathrm{Y} 1$ is job satisfaction

Y2 is employee performance

Tables 1 and 2 show the standardized probability values and coefficient values for all analyzed paths. Structural equation model as shown in Figure 1.

\section{Figure 1. Structural Equation Model}

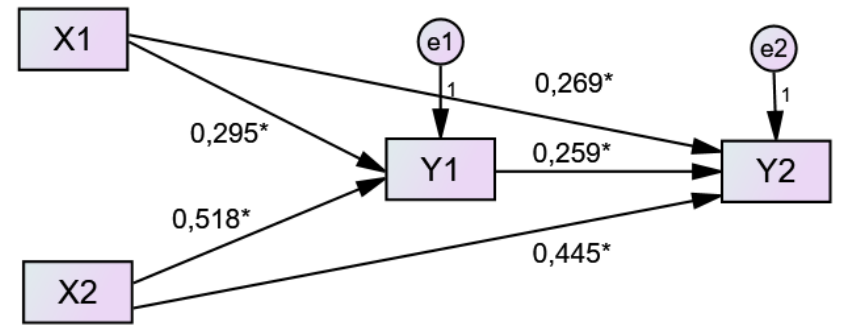

Regression equation 1: $\mathrm{Y} 1=0,295 \mathrm{X} 1+0,518 \mathrm{X} 2+\mathrm{e} 1$

Regression equation 2: Y2 $=0,269 \mathrm{X} 1+0,445 \mathrm{X} 2+0,259 \mathrm{Y} 1+\mathrm{e} 2$

Notes:

*) indicates the level of $p$. generated does not exceed $\alpha(0.05)$

$\mathrm{X} 1$ is work motivation

$\mathrm{X} 2$ is training

$\mathrm{Y} 1$ is job satisfaction

Y2 is employee performance

\section{DISCUSSION}

Work motivation is manifested by the need for achievement, the need for power and the need for affiliation. The findings of the descriptive analysis show that employee motivation is more indicated by efforts to fulfill 
achievement needs. Employee motivational behavior appears in efforts to achieve success at work. Employees with motivation to perform better prefer challenges, dare to take risks, can take over responsibilities, like to work hard. Employees are more concerned with satisfaction when the target has been achieved than rewards for performance. This does not mean that employees do not expect rewards, but that employees like challenges. As the opinion of Mangkunegara (2017: 93) states that motivation is a condition to move employees to achieve certain motives and goals.

The implementation of training can be observed from the quality of human resources, training quality, training methods, and training facilities. The implementation of training experienced by employees is more likely to feel the quality of the training. This is reflected in the undoubted ability of the coach. This job training is held with the aim that employees have the skills, abilities and knowledge following the demands of the employee's job. The right training makes employees work faster, more efficiently and effectively at work. As the opinion of Harras et al (2020) states that training is learning, practicing, testing, finding out, developing and realizing.

Job satisfaction can be measured from job satisfaction, promotion opportunities and co-workers. The results showed that the employees were satisfied with their ability to complete the work following the standards set. Employees who are satisfied with their work, tend to show behavior that is happy to cooperate, are more satisfied with existing conditions, are willing to comply with regulations, be careful in using bank equipment, can work together harmoniously, and work without complaints. As Afandi's opinion (2018) states that job satisfaction is a positive attitude of the workforce including feelings and behavior towards their work through the assessment of one job as a sense of appreciation in achieving one of the important values of the job.

Employee performance can be observed from the quantity, quality and timeliness. The results showed that the employees worked on time. This shows that employees can complete the work following the specified time that has been determined because the bank must maintain timeliness and quality. Employee performance according to Mangkunegara (2017) is the result of work in quality and quantity that can be achieved by an employee in carrying out tasks following the responsibilities given to him.

The results of the study prove that work motivation and training implementation can create job satisfaction. Work motivation to achieve achievement has a dominant influence in creating job satisfaction for bank employees. Likewise, work motivation and the implementation of training affect increasing their performance. Job training results in employees having skills and knowledge that have a positive impact on their performance.

The results of the study prove that motivation to achieve success has a positive impact on job satisfaction. The results of this study support Fatmawati et al. (2014), Ananto et al. (2016), Aziz (2016), Rahayu and Ajimat (2018), and Santika and Antasari (2019) who found that work motivation affected job satisfaction.

It is also proven that the implementation of the training results in the level of job satisfaction at work. Training for employees is very important to be applied to banks. The implementation of the training is expected for employees to work more effectively and efficiently, especially in dealing with changes that occur such as changes in technology, or changes in work methods. The results of this study support the research conducted by Supatmi et al. (2013) and Saprudin (2019) which prove that training affects job satisfaction.

Leaders should motivate subordinates according to their needs. Providing work motivation following the needs of employees can produce performance following the wishes of the company. The results of this study support Fatmawati et al. (2013), Aziz (2016), Indriansyah (2018), Santika and Antasari (2019) which prove that work motivation affects performance. The implementation of training has a direct impact on the performance of bank employees. The results of this study support Supatmi et al. (2013), Indriansyah (2018), Marjaya and Pasaribu (2019) which state that training affects performance.

Job satisfaction has a significant effect on employee performance, which means the higher the level of employee job satisfaction can improve employee performance. A previous study on satisfaction, Wahyudi et al (2017) proved that satisfaction has a significant direct impact on the net benefit, meaning higher satisfaction will lead to the higher performance. The view of Robbins and Judge (2017) states that job satisfaction is an individual's general attitude towards his work in which a person is required to interact with colleagues and superiors, follow the rules and policies of the organization to meet performance standards.

The effect of job satisfaction on performance as a result of this study supports previous research conducted by Supatmi et al. (2013), Fatmawati et al. (2014), Aziz (2016), Indriansyah (2018), Santika and Antasari (2019), and Sari and Hadijah (2016) which prove that job satisfaction affects performance.

The results this study showed that job satisfaction was able to mediate work motivation to improve employee performance. This means that motivation can improve employee performance if employees are satisfied with their work. The employee's assessment of the work with his condition is closely related to employee job satisfaction. The results of this study support Santika and Antari (2019) who found that motivation affects employee performance through job satisfaction.

The results showed also that employee job satisfaction was able to mediate the implementation of training on employee performance. This means that employee performance can be improved if the bank organizes training according to the needs of employees and employees are satisfied with their work. Job satisfaction is important for 
the bank, if the employee is satisfied with the job then the employee feels cared for by the bank. Job training at the bank is intended to develop and improve the attitudes, knowledge, behavior, and skills of employees.

\section{CONCLUSION}

Employee work motivation prefers to fulfill parties related to work performance. The implementation of the training can be reflected in the undoubted ability of the trainer. The job satisfaction of bank employees is reflected in their completion in completing the work according to the standard time set. Employee performance is seen in completing work on time. The results showed that employee job satisfaction was proven to mediate work motivation and training on employee performance. Job satisfaction is more able to anticipate the implementation of training than aspects of employee work motivation to improve employee performance. Unfortunately, job satisfaction is not able to become a strategy in the field of human resource management to improve employee performance. The work training programs that are regularly held by bank management have a direct impact on employee performance.

\section{BIBLIOGRAPHY}

Afandi, P. 2018. Manajemen Sumber Daya Manusia (Teori, Konsep dan Indikator). Riau: Zanafa Publishing.

Ananto, Setyo, I. Ketut Rahyuda, and Putu Saroyeni Priartrini. 2016. Pengaruh Motivasi Terhadap kepuasan Kerja dan Intensi Keluar Pada Asisten Kursus Metode Kumon di Bali dan Lombok. E-Jurnal Ekonomi dan Bisnis. Vol 5 No. 9: 3057-3086.

Anoraga, Panji. 2005. Psikologi Kerja. Rineka Cipta, Jakarta.

Aziz, M. Abdul. 2016. Pengaruh motivasi kerja, disiplin kerja dan lingkungan kerja terhadap kinerja melalui kepuasan kerja pada pegawai Puskesmas Kecamatan Balapulang Kabupaten Tegal. Multiplier: Jurnal Magister Manajemen. Vol. 1 No. 1.

Dessler, Gary. 2011. Manajemen Sumber Daya Manusia. Penerbit Indeks, Jakarta.

Fatmawati, Alvina Puspha, Wahyu Hidayat, and Reni Shinta Dewi. 2014. Pengaruh Motivasi, Kompensasi Melalui Kepuasan Kerja Terhadap Kinerja Karyawan. Jurnal Ilmu Administrasi Bisnis. No.3 No. 1: 239-248.

Harras, Hadyanti, Endang Sugiarti and Wahyudi. 2020. Kajian Manajemen Sumber Daya Manusia Untuk Mahasiswa. Other. Unpam Press, Tangerang Selatan.

Ibrahim. 2007. Penelitian dan Penilaian Pendidikan. Bandung : Sinar Baru Algensindo.

Indriansyah, Agung. 2018. Analisis Pengaruh Motivasi, Pelatihan dan Kepuasan Kerja Terhadap Kinerja Karyawan Pada PT Multi Data Palembang. Journal Management, Business, and Accounting. Vol 17 No. 2: 23-33.

Kasmir. 2016. Manajemen Sumber Daya Manusia (Teori dan Praktik). Depok: PT. Rajagrafindo Persada.

Mangkunegara,A.A. Anwar Prabu. 2017. Manajemen Sumber Daya Manusia. Perusahaan. Bandung : Remaja Rosdakarya.

Marjaya, Indra and Fajar Pasaribu. 2019. Pengaruh Kepemimpinan, Motivasi, Dan Pelatihan Terhadap Kinerja Pegawai. Maneggio: Jurnal Ilmiah Magister Manajemen. Vol 2 No. 1: 129-147.

Martoyo, Susilo. 2013. Manajemen Sumber Daya Manusia. BPFE. Yogyakarta.

Miftahun, Ni'mah and Sugiyanto, Suseno. 2010. Pengaruh Dukungan Sosial Dan Kepemimpinan Transformasional terhadap Komitmen Organisasi Mediator Kerja. Jurnal Psikologi. Vol. 37 No. 1: 94-109.

Rahayu, Eli and Mr Ajimat. 2018. Pengaruh Disiplin Kerja Terhadap Kinerja Pegawai Pada Sekretariat Deputi Bidang Pengembangan Destinasi Pariwisata. Jurnal Ekonomi Efektif. Vol. 1 No 1.

Riyadi, Slamet. 2006. Banking Assets And Liability Management. Jakarta : Fakultas Ekonomi Universitas Indonesia.

Robbins, Stephen P. and Timothy A. Judge. 2008. Perilaku Organisasi. Edisi ke-12,. Jakarta: Salemba Empat.

Robbins, Stephen P., and Timothy A. Judge. 2016. Perilaku Organisasi Edisi 16. Jakarta : Salemba Empat.

Robbins, P. Stephen and Judge, Timothy A. 2017.Organizational Behaviour, Edisi 13, Jilid 1, Salemba Empat, Jakarta.

Santika, I. Putu, and Ni Luh Sili Antari. 2019. Pengaruh Motivasi dan Lingkungan Kerja Terhadap Kinerja Karyawan melalui Kepuasan Kerja sebagai variabel Intervening di LPD desa adat Kerobokan. Jurnal Ilmiah Manajemen \& Akuntansi. Vol 25 No.1: 72-83.

Sanusi, Anwar. 2014. Metodologi Penelitian Bisnis. Jakarta: Salemba Empat.

Saprudin. 2018. Pengaruh Pelatihan Dan Kompensasi Terhadap Produktivitas Kerja Karyawan. Journal Of Information System, Applied, Management, Accounting And Research.Vol 2 No. 2: 35-40.

Saprudin, Ujang. 2019. Konsep bimbingan dan konseling spiritual: kerangka kerja untuk guru bimbingan dan konseling. Jurnal Penelitian Bimbingan dan Konseling. Vol 4 No 1.

Sari, Ririn Nur Indah and Hady Siti Hadijah. 2016. Peningkatan kinerja pegawai melalui kepuasan kerja dan disiplin kerja. Jurnal Pendidikan Manajemen Perkantoran (JPManper). Vol. 1 No.1: 204-214.

Supatmi, Mamik Eko, Umar Nimran, and Hamidah Nayati Utami. 2013. Pengaruh pelatihan, kompensasi terhadap 
kepuasan kerja karyawan dan kinerja karyawan. Profit: Jurnal Administrasi Bisnis. Vol 7 No.1: 25-37.

Vithessonthi and Schwaninger. 2008. Job motivation and self-confidence for learning and development as predictors of support for change. Journal of Organisational Transformation and Social Change. Volume 5 Number 2.

Yusuf, A, Muri.2015.Metode Penelitian Kuantitatif, Kualitatif \& Penelitian Gabungan. Kencana: Jakarta.

Wahyudi, Farid, Harianto Respati and Yusaq Tomo Ardianto. 2017. Study on DAPODIK Information System: User Satisfaction as Mediation of System Quality and Information Quality on Net Benefit. Information and Knowledge Management. Vo. 7. No. 7. pp 53-62. 